\title{
Human hepatocellular carcinoma cells resist to TRAIL-induced apoptosis, and the resistance is abolished by cisplatin
}

\author{
Eui-Cheol Shin ${ }^{1}$, Young Rim Seong ${ }^{2}$, \\ Chul Hoon $\mathrm{Kim}^{3}$, Hoguen $\mathrm{Kim}^{4}$, \\ Young Soo Ahn ${ }^{3}$, Kunhong Kim ${ }^{5}$, \\ Se Jong Kim ${ }^{1}$, Seung-Suh Hong ${ }^{2}$ and \\ Jeon Han Park ${ }^{1,6}$ \\ ${ }^{1}$ Department of Microbiology, Institute for Immunology and Immuno- \\ logical Diseases, \\ ${ }^{2}$ Therapeutic Gene Group, Team 1, Samyang Genex Biotech \\ Research Institute, Daejeon, \\ ${ }^{3}$ Department of Pharmacology, \\ ${ }^{4}$ Department of Pathology, Brain Korea 21 Project for Medical Sci- \\ ences, Yonsei University College of Medicine, Seoul, Korea. \\ ${ }^{5}$ Department of Biochemistry and Molecular Biology, Yonsei Univer- \\ sity College of Medicine, Seoul, Korea \\ ${ }^{6}$ Corresponding author: Tel, +82-2-361-5286; \\ Fax, +82-2-392-7088; E-mail, jhpark5277@ yumc.yonsei.ac.kr
}

Accepted 12 April 2002

Abbreviations: TRAIL, TNF-related apoptosis-inducing ligand; TNF, tumor necrosis factor; $\mathrm{DcR}$, decoy receptor; NF- $\mathrm{KB}$, nuclear factor- $\mathrm{KB}$; TRANCE, TNF-related activation-induced cytokine; FLIP, FLICE inhibitory protein; FLICE, FADD-like interleukin-1 $\beta$-converting enzyme; HCC, hepatocellular carcinoma; MTT, 3-(4-5-dimethylthiazol-2-yl)-2,5diphenyl tetrazolium bromide; HBV, hepatitis B virus; RPA, RNase protection assay; RT-PCR, reverse transcription-polymerase chain reaction; GAPDH, glyceraldehyde-3-phosphate dehydrogenase

\footnotetext{
Abstract:

TNF-related apoptosis-inducing ligand (TRAIL), a member of the TNF family, selectively induce apoptosis in various transformed cell lines but not in almost-normal tissues. It is regulated by 2 death receptors, TRAIL receptor 1 (TRAIL-R1) and TRAILR2 and 2 decoy receptors, TRAIL-R3 and TRAIL-R4. However, the determining factors of the sensitivity to TRAIL-induced apoptosis are not clearly understood. Herein, we investigated the expression of TRAIL-R, c-FLIP, FADD-like interleukin-1 $\beta$-converting enzyme inhibitory protein, and TRAlL-induced apoptosis in human hepatocellular carcinoma (HCC) cell lines. Seven of ten HCC cell lines showed resistance to TRAIL-induced apoptosis and five of seven TRAIL-resistant cell lines became sensitive to TRAIL by co-treatment with cycloheximide. In HCC cell lines, their TRAIL resistance did not correlate with
}

the basal expression level of TRAIL receptors or cFLIP, however, in human tissues, TRAIL-R1 and TRAIL-R2 expressions were notably decreased compared to normal counterpart. Cisplatin showed synergistic effect on TRAIL-induced apoptosis in most HCC cell lines regardless of their p53 status and TRAIL-R1 was induced by cisplatin treatment in certain cell lines. Inhibition of nuclear factor $\kappa B$ (NF- $\kappa B$ ) by SN50, a peptide inhibitor of NF-KB activity, had no effect on TRAIL-induced apoptosis in HCC cells. These results suggest that (a) the majority of human HCC cell lines are resistant to TRAIL-induced apoptosis and cycloheximide-sensitive short-lived antiapoptotic molecule(s) is responsible for this resistance, (b) the expression of TRAIL-R1 and TRAIL-R2 is reduced in HCC tissues, and the increased expression of TRAIL-R1 may be a mechanism of cisplatininduced sensitization to TRAIL-induced apoptosis in some HCC cells, and (c) the activation of NF-KB may not be involved in the TRAIL resistance of HCC cells

Keywords: TRAIL, apoptosis, HCC, cisplatin, cycloheximide

\section{Introduction}

TNF-related apoptosis-inducing ligand (TRAIL) is one of the apoptosis-inducing molecules belonging to the tumor necrosis factor (TNF) family (Wiley et al., 1995; Pitti et al., 1996). Four different membrane-bound receptors for TRAIL have been identified. Among these, TRAIL-R1 (DR4) and TRAIL-R2 (DR5) are typical death receptors, and belong to the death receptor family containing a death domain in their cytoplasmic tails (Pan et al., 1997a; Pan et al., 1997b; Screaton et al., 1997; Sheridan et al., 1997; Walczak et al., 1997). However, TRAIL-R3 (DcR1; TRID) and TRAIL-R4 (DcR2) are decoy receptors that have no or short cytoplasmic tail respectively, which lack a death domain (Degli-Esposti et al., 1997a; Degli-Esposti et al., 1997b; Pan et al., 1997a; Sheridan et al., 1997; Mongkolsapaya et al., 1998; Pan et al., 1998). When TRAIL binds to its receptors, TRAIL-R1 and TRAIL-R2 consign cells to the apoptotic process, while TRAIL-R3 and TRAIL-R4 prevent apoptosis by competing with TRAIL-R1 or TRAIL-R2 in the binding to TRAIL. Meanwhile, TRAILR1, TRAIL-R2 and TRAIL-R4 are able to activate nuclear factor-kB (NF-kB) (Chaudhary et al., 1997; Degli-Esposti et al., 1997a; Schneider et al., 1997), 
which can transactivate anti-apoptotic gene expression and therefore suppress apoptotic process (Beg and Baltimore, 1996; Van Antwerp et al., 1996; Wang et al., 1996). In addition, osteoprotegerin, a soluble receptor for TNF-related activation-induced cytokine (TRANCE), also binds to TRAIL (Emery et al., 1998), and may act as a third decoy receptor.

TRAIL had been considered as a candidate of the selective anti-cancer drug (Ashkenazi et al., 1999; Walczak et al., 1999), because it had been reported that TRAIL induced apoptosis only in tumor cells but not in normal cells. Initially, the deficiency of TRAIL-R3 expression in tumor cells was suspected as a mechanism of tumor-specific TRAIL toxicity (Gura, 1997). However, this decoy hypothesis is no longer accepted due to the absence of a correlation between TRAIL sensitivity and TRAIL-R3 expression (Griffith and Lynch, 1998; Griffith et al., 1999a). Although the exact determinant of TRAIL sensitivity is unclear, the extent of cellular FLICE inhibitory protein (c-FLIP) expression (Griffith et al., 1998; Kim et al., 2000) and the loss of FADD-like interleukin-1 $\beta$-converting enzyme (FLICE; caspase-8) expression (Grotzer et al., 2000) have been raised as another possible determining factors.

TRAIL has been implicated to play a role as an effector molecule in the anti-tumor action of immune cells such as $\mathrm{T}$ cells and monocytes (Thomas and Hersey; 1998; Griffith et al., 1999b; Kayagaki et al., 1999) and also as an anti-tumor effector molecule in surveillance of tumor metastasis for natural killer cells in liver (Takeda et al., 2001). To better understand the definitive role of TRAIL, we examined human hepatocellular carcinoma (HCC) cell lines for the sensitivity to TRAIL-induced apoptosis, and the mRNA expression of TRAIL receptors and c-FLIP in $\mathrm{HCC}$ cell lines and tissues. We also investigated the effect of cycloheximide, cisplatin, and SN50, a peptide inhibitor of NF-кB on the sensitivity to TRAIL-induced apoptosis for the clarification of the TRAIL resistance mechanism in HCC cells.

\section{Materials and Methods}

\section{Reagents}

Recombinant human TRAIL was obtained from R\&D Systems (Minneapolis, MN, USA). Cycloheximide, cisplatin and 3-(4-,5-dimethylthiazol-2-yl)-2,5-diphenyl tetrazolium bromide (MTT) were obtained from Sigma (St. Louis, MO, USA). NF-кB-specific inhibitor, SN50 is a cell-permeable peptide containing nuclear localization sequence of NF- $\mathrm{KB}$ p50 and the signal peptide of Kaposi fibroblast growth factor (Lin et al., 1995). SN50 and SN50M, control peptide of SN50, were obtained from Biomol (Plymouth Meeting, PA, USA).

\section{Cell lines and cell culture}

Hep G2, Hep 3B and PLC/PRF/5 were obtained from the American Type Culture Collection (Rockville, MD, USA). Hep G2.2.15 cells, stable transfectants of the hepatitis B virus (HBV) genome into Hep G2 (Sells et al., 1987), were also included. These cell lines were grown in MEM containing 10\% fetal calf serum (Gibco BRL, Grand Island, NY, USA). SNU-182, SNU-354, SNU-368, SNU-387, SNU-398, and SNU-449 were obtained from the Korean Cell Line Bank (Seoul, Korea) (Park et al., 1995), and were grown in RPMI 1640 containing $10 \%$ fetal calf serum. All media contained $100 \mathrm{U} / \mathrm{ml}$ of penicillin and $100 \mu \mathrm{g} / \mathrm{ml}$ of streptomycin.

\section{Preparation of HCC tissues}

HCC and adjacent non-tumorous tissues were obtained immediately after surgical resection. The tissues were rapidly frozen in liquid nitrogen and stored at $-70^{\circ} \mathrm{C}$ until RNA preparation (Shin et al., 1998).

\section{MTT assay}

Cell viability was assessed by MTT assay (Gerlier and Thomasset, 1986). Briefly, $10^{4}$ cells were seeded to 96well plate in $100 \mu \mathrm{l}$ medium and left overnight to adhere. Then, $100 \mu \mathrm{l}$ medium containing recombinant TRAIL was added. After $24 \mathrm{~h}, 50 \mu \mathrm{l}$ of $2 \mathrm{mg} / \mathrm{ml}$ MTT solution was added to each well and incubated for another $4 \mathrm{~h}$ at $37^{\circ} \mathrm{C}$. The plates were then centrifuged at $200 \mathrm{~g}$ for $10 \mathrm{~min}$ and the supernatant was discarded. Then, $50 \mu \mathrm{l}$ of dimethyl sulfoxide was added to each well, and the plates were shaken until the crystals dissolved. Reduced MTT was then measured spectrophotometrically in a dual beam microtiter plate reader at $570 \mathrm{~nm}$ with a $650 \mathrm{~nm}$ reference.

\section{Analysis of oligonucleosomal DNA fragments}

The formation of oligonucleosomal DNA fragments was investigated using agarose gel electrophoresis (Jiang et al., 1999). Briefly, cells were treated with TRAIL and/or cycloheximide. After $24 \mathrm{~h}$, both floating and adherent cells were collected and resuspended in $250 \mu \mathrm{TE}$ buffer. The suspensions were then mixed with an equal volume of lysis buffer containing $20 \mathrm{mM}$ EDTA, $0.05 \%$ $(\mathrm{v} / \mathrm{v})$ Triton $\mathrm{X}-100$ and $10 \mathrm{mM}$ Tris. $\mathrm{Cl}, \mathrm{pH}$ 8.0. After 30 min-incubation on ice, the lysates were centrifuged and the fragmented DNA in supernatant was precipitated with ethanol. DNA was resuspended in $20 \mu \mathrm{l}$ TE buffer, incubated subsequently with RNase $A$, and thereafter with proteinase $\mathrm{K}$. Electrophoresis was performed for at $70 \mathrm{~V}$ on $1.8 \%$ agarose gels. The gel was stained with ethidium bromide and visualized with UV light.

\section{RNA extraction and RNase protection assay (RPA)}

Total cellular RNA was isolated from the HCC cells or tissues with RNeasy kit (Qiagen, Santa Claris, CA, USA). RPA was performed with RiboQuant ${ }^{\mathrm{TM}}$ multi-probe RPA kit (Pharmingen, San Diego, CA, USA) according 
to the method described previously (Shin et al., 1998). ${ }^{32} \mathrm{P}$-labeled antisense riboprobes were synthesized with hAPO-3c template set, $2.75 \mathrm{mM}$ ATP, GTP, CTP, 100 $\mu \mathrm{Ci}\left[\alpha^{-32} \mathrm{P}\right]$-UTP $(3000 \mathrm{Ci} / \mathrm{mmol}, \mathrm{NEN}$, Boston, MA, USA) and $20 \mathrm{U}$ T7 RNA polymerase. ${ }^{32} \mathrm{P}$-labeled antisense riboprobes were hybridized with $10 \mu \mathrm{g}$ of total cellular RNA at $56^{\circ} \mathrm{C}$ for $16 \mathrm{~h}$. After hybridization, $20 \mathrm{ng}$ of RNase $A$ and $50 \mathrm{U}$ of RNase T1 were added to digest unhybridized RNA. Duplex RNA hybrids were loaded onto $6 \%$ denaturing polyacrylamide gel containing $8 \mathrm{M}$ urea and visualized by autoradiography.

\section{Semiquantitative RT-PCR}

cDNA was synthesized from $5 \mu \mathrm{g}$ of total cellular RNA using $2 \mu \mathrm{g}$ of random hexamer (Pharmacia, Uppsala, Sweden), $1.25 \mathrm{mM}$ dNTP (Boehringer Mannheim, Mannheim, Germany) and $200 \mathrm{U}$ M-MLV reverse transcriptase (Gibco BRL). PCR was performed using 0.25 $\mathrm{mM}$ dNTP, $0.25 \cup$ Taq polymerase (Perkin Elmer, Branchburg, NJ, USA), 10 pmole primer pairs, and cDNA in a thermal cycler (Perkin Elmer). The following primer pairs were used: TRAIL-R3: 5'-GAT CCC CAA GAC CCT AAA GTT-3' and 5'-GGT TTC CAC AGT GGC ATT GGC3'; TRAIL-R4: 5'-AGG GAT GGT CAA GGT CAG TAA T3 ' and 5'-GAT GTC AGC GGA GTC AGC GTC A-3'; osteoprotegerin: 5'-GAA CCC CAG AGC GAA ATA CA-3' and 5'-CGC TGT TTT CAC AGA GGT CA-3'; c-FLIP: 5'GGG AGA AGT AAA GAA CAA AG-3' and 5'-CGT AGG CAC AAT CAC AGC AT-3'; $\beta$-actin: 5'-CGT GGG CCG

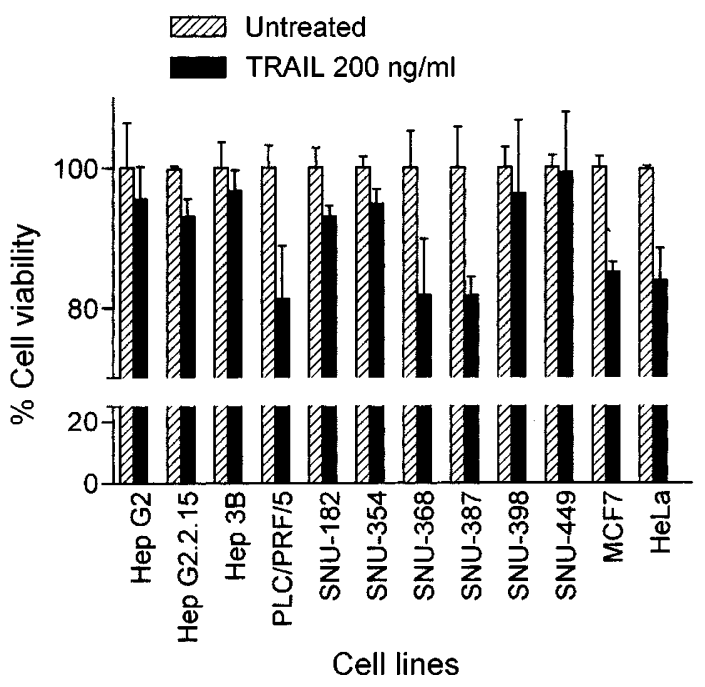

Figure 1. TRAIL-induced apoptosis in HCC cell lines. HCC cell lines were treated with $200 \mathrm{ng} / \mathrm{ml}$ of TRAIL for $24 \mathrm{~h}$ and an MTT assay was performed to evaluate cell viability. MCF7 and HeLa cells were used as the TRAILsensitive positive controls. Each bar and vertical line represents the mean and the standard error of the mean of four independent experiments.
A
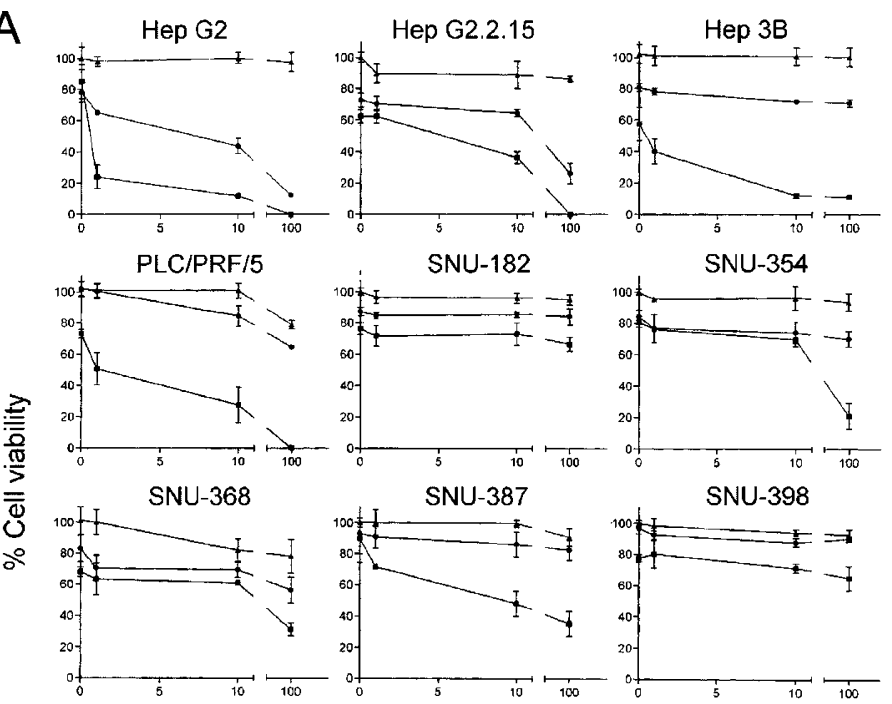

SNU-449

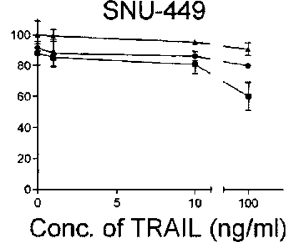

Conc. of cycloheximide $(\mu \mathrm{g} / \mathrm{ml})$

$$
\begin{aligned}
& \rightarrow 0 \\
& \rightarrow 0.5 \\
& \rightarrow-5
\end{aligned}
$$

B

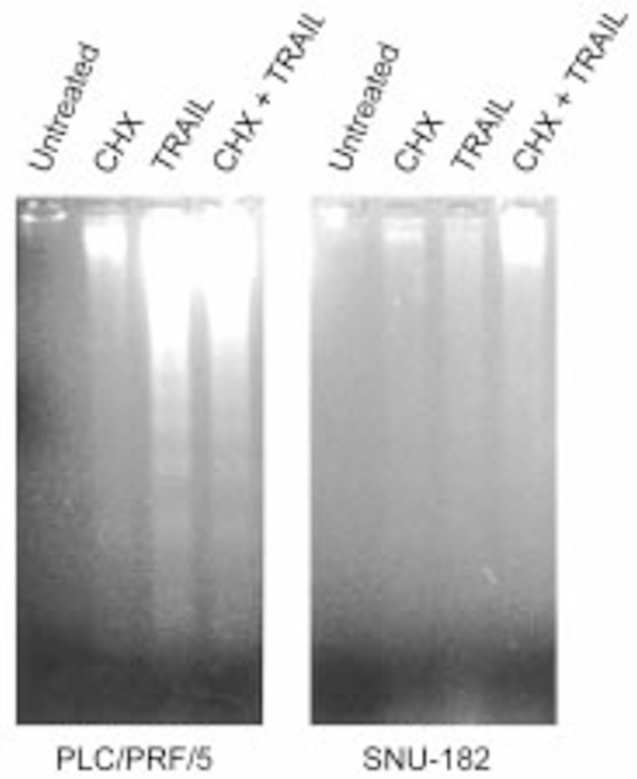

Figure 2. Effect of cycloheximide on TRAIL-induced apoptosis in HCC cell lines. A. HCC cell lines were treated simultaneously with various combinations of TRAIL and cycloheximide at the indicated concentrations for $24 \mathrm{~h}$. MTT assay was performed to evaluate cell viability. Each dot and vertical line represents the mean and the standard error of the mean of four independent experiments. B. HCC cell lines were treated with $100 \mathrm{ng} / \mathrm{ml} \mathrm{TRAlL} \mathrm{and/or} 1 \mu \mathrm{g} / \mathrm{ml}$ cycloheximide $(\mathrm{CHX})$ for $24 \mathrm{~h}$. Oligonucleosomal DNA fragmentation was assessed by electrophoresis. Representative results of PLC/PRF/5 and SNU-182 are shown. 
AGG GGG G-3'. The PCR cycling conditions used were: denaturation at $94^{\circ} \mathrm{C}$ for $30 \mathrm{~s}$, annealing at $56^{\circ} \mathrm{C}$ for $30 \mathrm{~s}$, and extension at $72^{\circ} \mathrm{C}$ for $1 \mathrm{~min}$. The optimal number of PCR cycles for semiquantitation was previously determined for each gene.

\section{Results}

Resistance to TRAIL and the effect of cycloheximide on TRAIL-induced apoptosis in HCC cell lines

To investigate the sensitivity to TRAIL-induced apoptosis in human HCC cell lines, ten HCC cell lines were treated with $200 \mathrm{ng} / \mathrm{ml}$ TRAIL for $24 \mathrm{~h}$ and cell survival was assessed by MTT assay. Three HCC cell lines, PLC/PRF/5, SNU-368 and SNU-387, were sensitive to TRAIL, and the other seven HCC cell lines were resistant (Figure 1).

Cycloheximide, a protein synthesis inhibitor, was found to sensitize cancer cells to TRAIL (Ahmad and Shi, 2000; Leverkus et al., 2000) or FasL (Kim et al., 2000). HCC cell lines treated with various combinations of TRAIL and cycloheximide for $24 \mathrm{~h}$ was assessed for cell survival. With $0.5 \mu \mathrm{g} / \mathrm{ml}$ cycloheximide, only Hep G2 and Hep G2.2.15 were sensitized to TRAIL. At $5 \mu \mathrm{g} / \mathrm{ml}$ cycloheximide, Hep 3B, SNU-354, and SNU-449 became sensitized to TRAIL, but SNU-182 and SNU398 were still resistant (Figure 2A).

TRAIL-induced apoptosis was evaluated by oligonucleosomal DNA fragmentation. Representative data for PLC/PRF/5 and SNU-182 are shown in Figure 2B. Typical DNA ladder formation was observed by treatment with $100 \mathrm{ng} / \mathrm{ml}$ TRAIL in PLC/PRF/5 cells. However, SNU-182 cells did not show DNA ladder formation, even in the presence of cycloheximide.

\section{Expression of TRAIL receptors and c-FLIP in HCC cell lines}

To clarify the molecular determinants of TRAIL sensitivity in HCC cell lines, the mRNA expression of TRAIL receptors and c-FLIP in HCC cell lines was investigated. The mRNA expressions of TRAIL-R1, TRAIL-R2 and TRAIL-R3 were examined with RPA (Figure 3A). In HCC cell lines, TRAIL-R2 was more abundantly expressed, however the basal expression levels of pro-apoptotic TRAIL-death receptors such as TRAIL-R1 and TRAILR2 showed no correlation with the sensitivity to TRAIL. The expression level of FLICE also showed no correlation with the TRAIL sensitivity. Transcripts of TRAIL-R3 could not be detected with RPA. The mRNA expressions of the decoy receptors for TRAIL and the intracellular FLICE inhibitor, c-FLIP, were examined by semiquantitative RT-PCR (Figure 3B). TRAIL-R3 transcripts were detected in several cell lines, however their expression was very weak. TRAIL-R4 and c-FLIP were
A
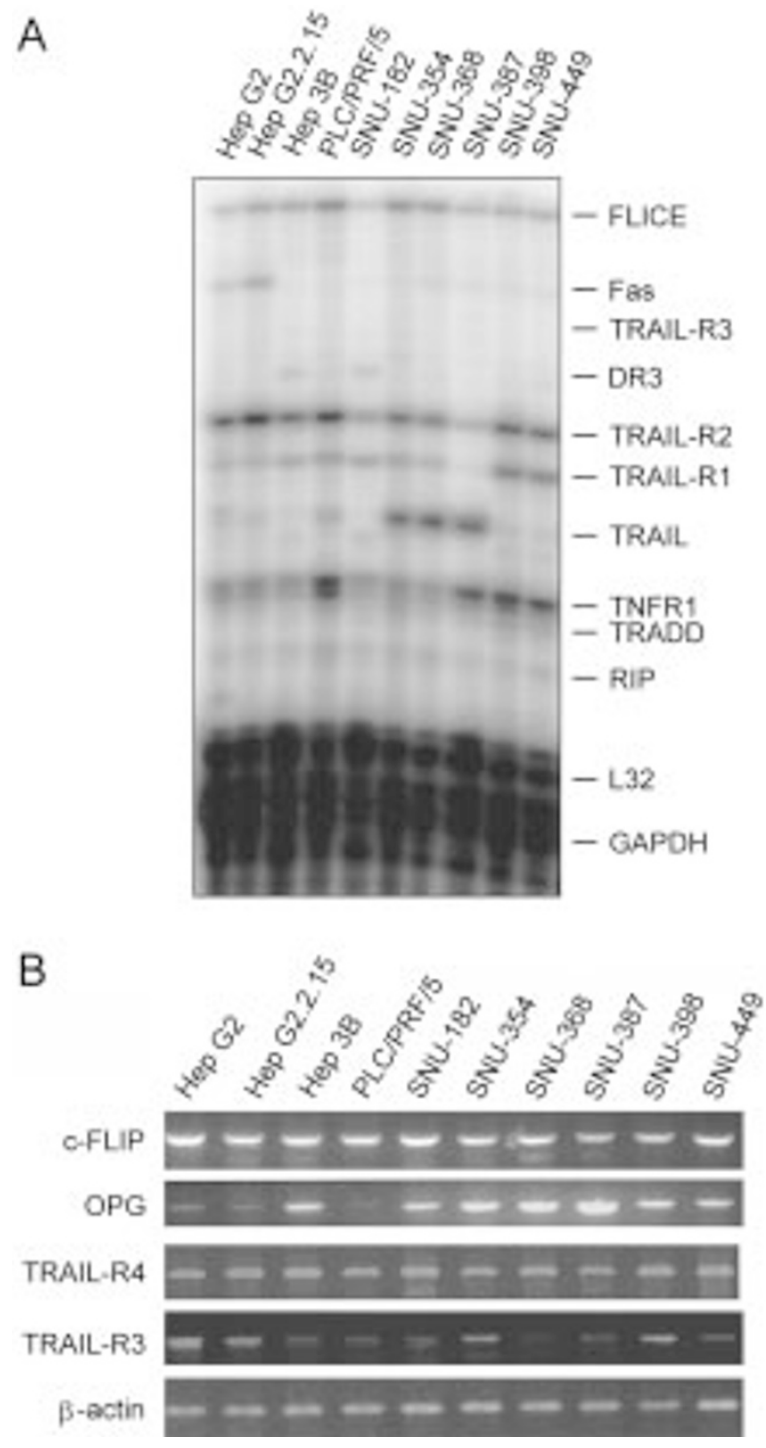

Figure 3. The mRNA expression of TRAIL receptors and c-FLIP in HCC cell lines. A. The mRNA expression of TRAIL-R1, TRAIL-R2, TRAIL-R3 and FLICE was examined by RPA in HCC cell lines. The expression of $L 32$ and glyceraldehyde-3-phosphate dehydrogenase (GAPDH) was examined for the quantitation of internal control. B. The mRNA expression of TRAIL-R3, TRAIL-R4, osteoprotegerin (OPG) and c-FLIP was examined by semiquantitative RT-PCR.

expressed in all HCC cell lines and osteoprotegerin was expressed in several cell lines. However, the expression level of decoy receptors and c-FLIP also showed no correlation with the TRAIL sensitivity.

\section{Expression of TRAIL receptors and c-FLIP in HCC tissues}

In order to enhance the detection sensitivity of the expression level of TRAIL receptors and c-FLIP between normal and cancer, RPA or semiquantitative RT-PCR was used using RNA isolated from 4 pairs of 


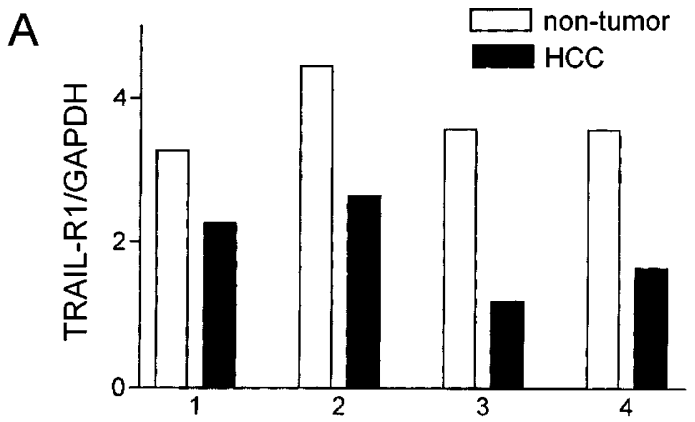

B

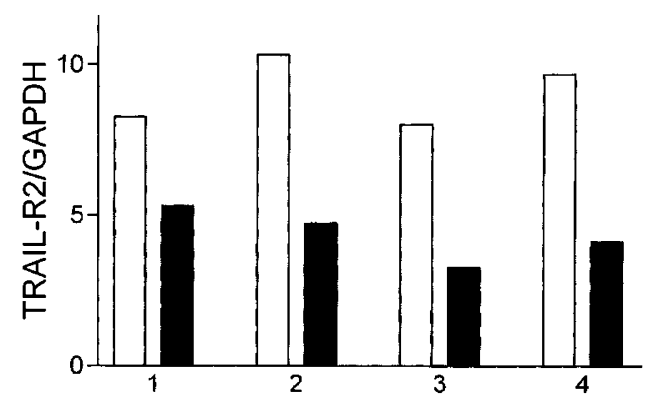

C
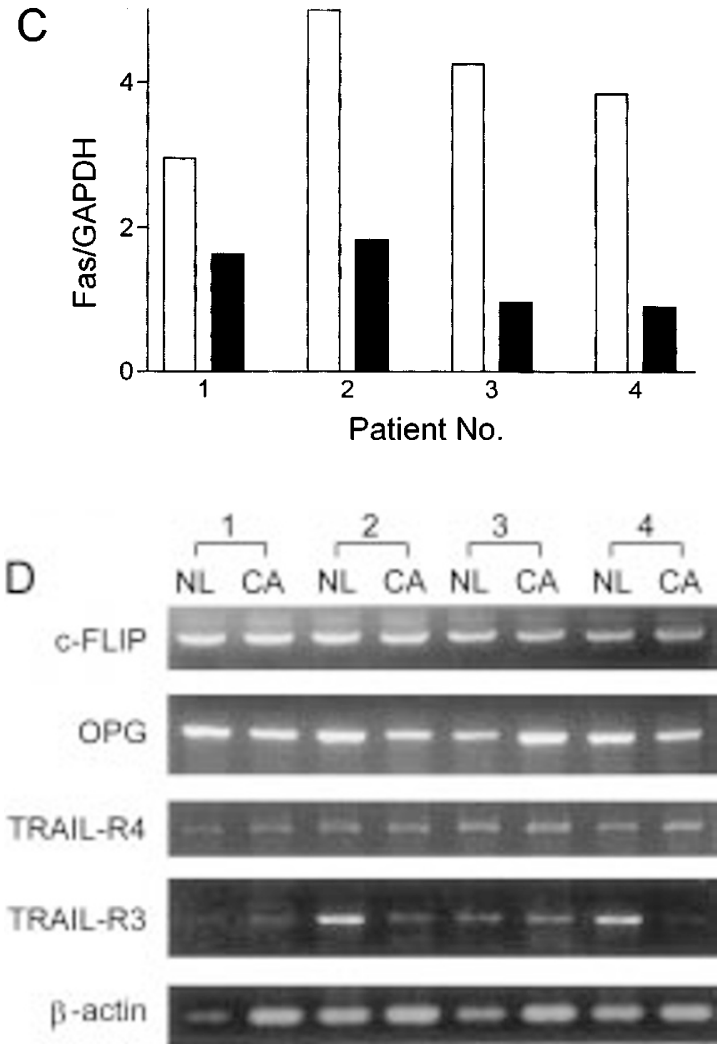

Figure 4. The mRNA expression of TRAIL receptors and c-FLIP in HCC tissues and paired non-malignant liver tissues. The mRNA expression of TRAIL-R1, TRAIL-R2, and Fas was examined by RPA. The relative intensities of TRAIL-R1 (A), TRAIL-R2 (B) and Fas (C) are presented in the histogram. The relative intensity is the ratio of the band density of the gene of interest to that of the internal control, GAPDH. The mRNA expression of TRAIL-R3, TRAIL-R4, osteoprotegerin (OPG) and c-FLIP was examined by semiquantitative RT-PCR (D). human HCC and their adjacent normal liver tissues. All of the HCC tissues showed lower levels of TRAIL-R1 and TRAIL-R2 expressions in comparison with the paired non-malignant liver tissues (Figure $4 \mathrm{~A}$ and $\mathrm{B}$ ). Fas expression was also found to be lower in the HCC tissues (Figure 4C) as previously reported (Shin et al., 1998). In two cases (patient No. 2 and 4), TRAIL-R3 was remarkably expressed only in non-malignant liver tissues (Figure 4D). TRAIL-R4, osteoprotegerin and cFLIP did not show any significant difference in HCC and non-malignant liver tissues.

\section{Synergistic effect of cisplatin on TRAIL-induced apoptosis in HCC cells}

Chemotherapeutic anti-cancer drugs sensitize many tumor cells to TRAIL (Keane et al., 1999; Gibson et al., 2000; Nagane et al., 2000). Examination of cisplatin effect on TRAIL-induced apoptosis in HCC cell lines showed that cisplatin induced synergistic effect on TRAIL-induced apoptosis in all the HCC cell lines except SNU-387, in which cisplatin showed additive effect (Figure 5). This synergistic effect of cisplatin appeared even in SNU-182 and SNU-398, which were resistant to the TRAIL and cycloheximide combination treatment. In addition, cisplatin showed synergistic effect on TRAIL-induced apoptosis regardless of p53 status of $\mathrm{HCC}$ cell lines: Hep 3B is deficient of p53 and PLC/PRF/5, SNU-182, SNU-354, SNU-368 and SNU-449 do not express wild type p53 (Kang et al., 1996; Jia et al., 1997).

To elucidate the mechanism of cisplatin-induced

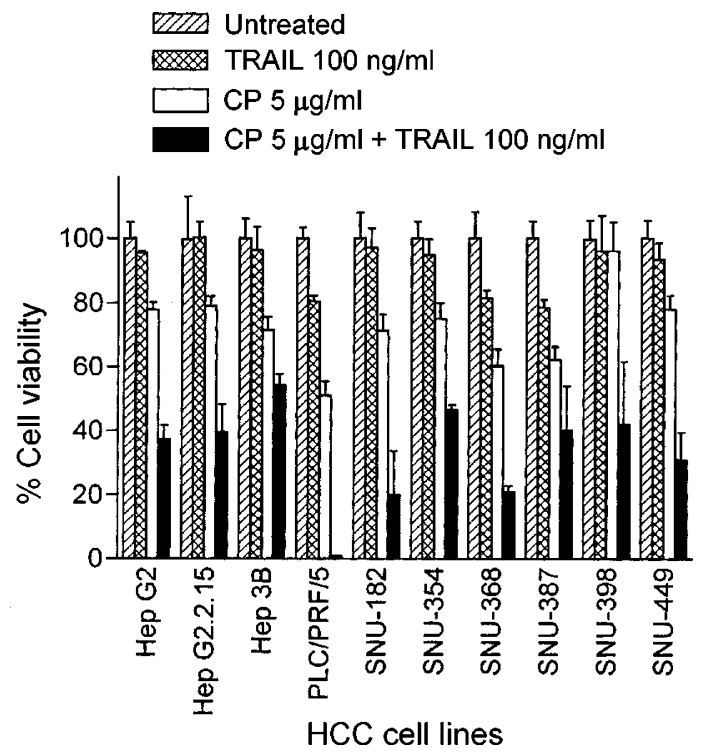

Figure 5. Effect of cisplatin on TRAlL-induced apoptosis in HCC cell lines. $\mathrm{HCC}$ cell lines were treated with $100 \mathrm{ng} / \mathrm{ml}$ TRAlL and/or $5 \mu \mathrm{g} / \mathrm{ml}$ cisplatin (CP) for $24 \mathrm{~h}$. MTT assay was performed to evaluate cell viability. Each bar and vertical line represents the mean and the standard error of the mean of four independent experiments. 


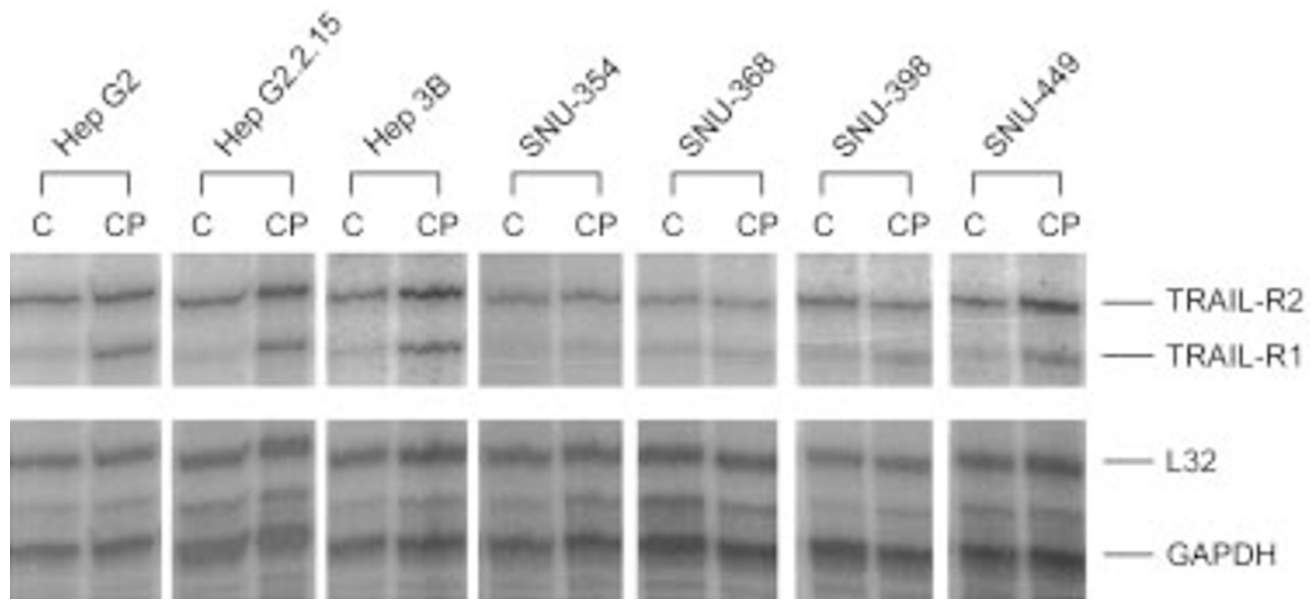

Figure 6. Effect of cisplatin on the mRNA expression of TRAIL-R1 and TRAIL-R2 in HCC cell lines. HCC cell lines were treated with (CP) or without (C) 5 $\mu \mathrm{g} / \mathrm{ml}$ cisplatin for $12 \mathrm{~h}$, and the mRNA expression of TRAIL-R1 and TRAlL-R2 was examined by RPA. The expression of L32 and GAPDH was examined for the quantitation of internal control.

A

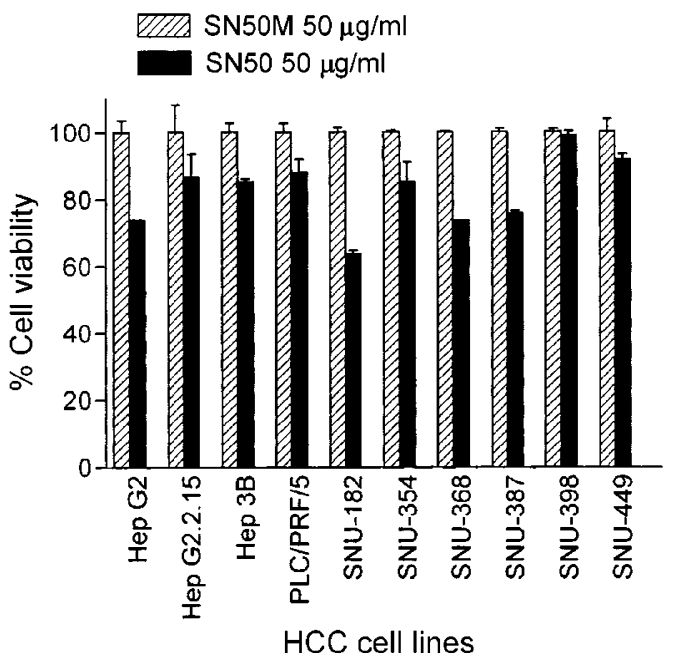

B WIIA SN50M $50 \mu \mathrm{g} / \mathrm{ml} \&$ TRAIL $100 \mathrm{ng} / \mathrm{ml}$ SN50 $50 \mu \mathrm{g} / \mathrm{ml} \&$ TRAIL $100 \mathrm{ng} / \mathrm{ml}$

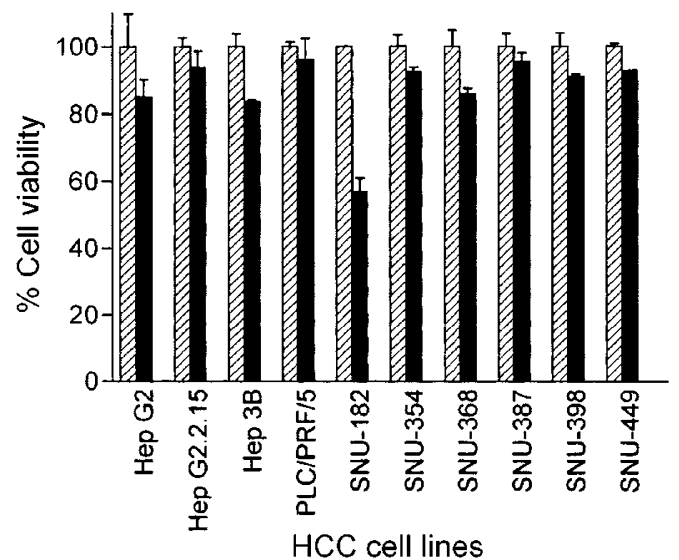

Figure 7. Effect of NF- $\mathrm{KB}$ inhibitor, SN50 on TRAIL-induced apoptosis in HCC cell lines. HCC cell lines were treated for $24 \mathrm{~h}$ with either SN50, a peptide inhibitor of NF- $\mathrm{KB}$, or SN50M, the control peptide (A). In the presence of $100 \mathrm{ng} / \mathrm{ml}$ TRAlL, HCC cell lines were treated with SN50 or SN50M for $24 \mathrm{~h}(\mathbf{B})$. MTT assay was performed to evaluate cell viability. Each bar and vertical line represents the mean and the standard error of the mean of four independent experiments. The increment of TRAIL-induced apoptosis by SN50 is no greater than the reduction of basal viability caused by SN50.

augmentation of TRAlL-induced apoptosis, we investigated the changes in the mRNA expression of deathmediating TRAIL receptors, TRAIL-R1 and TRAIL-R2 after cisplatin treatment in HCC cell lines. In Hep G2, Hep G2.2.15, Hep 3B and SNU-449, the expression of TRAIL-R1 was obviously increased by cisplatin treatment (Figure 6). However, the expression of TRAILR2, TRAIL receptor known as DNA damage-responsive gene, was not markedly changed, although slight upregulation was shown in Hep 3B and SNU-449. The increased expression of TRAIL-R1 or TRAIL-R2 was independent of p53 status in $\mathrm{HCC}$ cell lines.

\section{No effect of NF-kB inhibitor, SN50 on TRAIL-induced apoptosis in HCC cells}

TRAIL-R1, TRAIL-R2 and TRAIL-R4 are able to activate NF-кB (Chaudhary et al., 1997; Degli-Esposti et al., 1997a; Schneider et al., 1997), and the inhibition of NF-KB activity make cells sensitive to TNF- $\alpha$-induced apoptosis (Beg and Baltimore, 1996; Van Antwerp et al., 1996; Wang et al., 1996). Thus, the inhibition of NF-KB activity might induce cells become sensitive to TRAIL. SN50, a peptide inhibitor of NF-KB, suppressed cell viability in the majority of HCC cell lines without TRAIL (Figure 7A), however, 
SN50 did not reduce the resistance to TRAIL (Figure $7 B$ ). These results suggest that NF- $\kappa B$ activation may not be responsible for the resistance to TRAILinduced apoptosis in HCC cells.

\section{Discussion}

The majority of HCC cell lines examined here showed resistance to TRAIL despite the report that variety of tumor cells have responded to TRAlL-induced apoptosis. A similar finding of resistance to TRAIL-induced apoptosis was reported on different HCC cell lines (Yamanaka et al., 2000). TRAIL has been reported to play a role as an effector molecule in the anti-tumor action of immune cells such as T cells and monocytes (Thomas and Hersey, 1998; Griffith et al., 1999b; Kayagaki et al., 1999). Natural killer cells utilize TRAIL as an anti-tumor effector molecule in surveillance of tumor metastasis in liver (Takeda et al., 2001). Augmention of TRAIL-induced apoptosis observed here with cycloheximide and cisplatin suggest that antiapoptotic protein(s) with relatively short half-life such as c-FLIP may be involved in the TRAIL resistance in HCC cell lines. In the presence of a subtoxic level of actinomycin D, a transcription inhibitor, TRAIL induced significant apoptosis in $\mathrm{HCC}$ cell lines (Yamanaka et al., 2000). However, the fact that two HCC cell lines were still resistant to TRAIL even in the presence of cycloheximide, may suggest that in those two cell lines there might be another mechanism(s) for the resistance. The augmentation of TRAIL-induced apoptosis by chemotherapeutic drugs is a well-known phenomenon (Keane et al., 1999; Gibson et al., 2000; Nagane et al., 2000, Yamanaka et al., 2000). Such augmentation by anticancer drugs was anticipated when TRAIL-R2 was cloned as a p53-responsive gene (Wu et al., 1997). Our results showed that synergistic effect of cisplatin on TRAIL-induced apoptosis was independent of p53 status in HCC cell lines. Among the HCC cell lines used in the present study, Hep 3B is deficient of p53 and PLC/PRF/5, SNU-182, SNU-354, SNU-368 and SNU449 do not express wild type p53 (Kang et al., 1996; Jia et al., 1997). It may be worthwhile to identify the mechanism of cisplatins effect in these cell lines. The mRNA expression of TRAIL-R1 was increased by cisplatin treatment in several $\mathrm{HCC}$ cell lines, without any correlation to their p53 status. The expression of Fas, another death receptor, is up-regulated by cisplatin only in HCC cell lines with wild-type p53 (Muller et al., 1997; Jiang et al., 1999). However, up-regulation of TRAIL-R1 may not be a sole explanation for synergistic cell killing, because there were some cell lines that showed more effective synergistic cell death without up-regulation of TRAIL-R1 expression. Direct or indirect insult of cisplatin on mitochondria after DNA damage could be additional mechanisms for the synergistic cell death (Choi et al., 2000).

In TNF- $\alpha$-induced apoptosis, inhibition of NF- $\kappa B$ activity induced cells to become sensitive to apoptosis (Beg and Baltimore, 1996; Van Antwerp et al., 1996; Wang et al., 1996) and TRAIL-R1, TRAIL-R2 and TRAIL-R4 were able to activate NF-kB (Chaudhary et al., 1997; Degli-Esposti et al., 1997a; Schneider et al., 1997). The inhibition of NF-KB activity made cells sensitive to TRAIL-induced apoptosis (Jeremias et al., 1998; Goke et al., 2000; Franco et al., 2001; Oya et al., 2001). However, we found that NF-KB inhibitor, SN50 treatment of human $\mathrm{HCC}$ cells caused no effect on the TRAIL-induced cellular apoptosis. Such discrepancy may be due to the different specificity of the NF-kB inhibitor used. We used the NF-kB-specific inhibitor, SN50, which is a cell-permeable peptide containing nuclear localization sequence of NF-kB p50 and the signal peptide of Kaposi fibroblast growth factor (Lin et al., 1995), however, the others used the non-degradable IKB $\alpha$ mutant (Jeremias et al., 1998; Franco et al., 2001; Oya et al., 2001) or sulfasalazine (Goke et al., 2000). Another possible cause of this discrepancy may be the difference of cell types. Our results suggested that NF$\kappa B$ activation may not be responsible for TRAIL resistance in HCC cells and this conclusion could be supported by the previous report that TRAIL resistance was found to be unrelated to TRAIL-induced NF- $\kappa B$ activity in HCC cell lines (Yamanaka et al., 2000), however this result should be confirmed with various NF-kB-inhibiting systems.

When TRAIL-R3, the first decoy receptor, was cloned, the expression of TRAIL-R3 was considered to be the major determinant of sensitivity in TRAIL-induced apoptosis (Gura, 1997). However, no concordant correlation was found between TRAIL-R3 expression and resistance to TRAIL-induced apoptosis (Griffith and Lynch, 1998; Griffith et al., 1999a). The expression level of c-FLIP has been focused as a mechanism for TRAIL resistance (Griffith et al., 1998; Kim et al., 2000), and recently, the loss of FLICE expression was considered as another possible mechanism (Grotzer et al., 2000). Our results revealed that no consistent correlations were found between the resistance of HCC cells to TRAIL to the expression levels of any TRAIL receptors, c-FLIP or FLICE. It is likely that there may be no universal determining factor and each HCC cell line may have specific mechanisms in this regard. The examination of TRAIL receptors and C-FLIP expression in HCC tissues and in the non-malignant liver showed that the expression of TRAIL-R1 and TRAIL-R2 was down-regulated in HCCs tissues compared with the adjacent non-malignant liver. Such findings are similar to that of Fas, another death-mediating receptor (Shin et al., 1998).

In conclusion, the majority of human $\mathrm{HCC}$ cells were 
found resistant to TRAIL, suggesting that this resistance may be requisite for HCC formation. In addition, cycloheximide-sensitive short-lived anti-apoptotic molecule(s) was responsible for the resistance to TRAILinduced apoptosis, but activation of NF-KB may not be involved in this resistance. Furthermore, the expression of TRAIL-R1 and TRAIL-R2 was found reduced in HCC tissues, and the increased expression of TRAIL-R1 may be the mechanism of cisplatin-induced sensitization to TRAIL-induced apoptosis in some HCC cells.

\section{Acknowledgements}

This work was supported by Grant (HMP-98-M-5-0057) of the 1998 Good Health R \& D Project from the Ministry of Health and Welfare, Korea.

\section{References}

Ahmad M, Shi Y. TRAIL-induced apoptosis of thyroid cancer cells: potential for therapeutic intervention. Oncogene 2000;19:3363-71

Ashkenazi A, Pai RC, Fong S, Leung S, Lawrence DA, Marsters SA, Blackie C, Chang L, McMurtrey AE, Hebert A, Deforge L, Koumenis IL, Lewis D, Harris L, Bussiere J, Koeppen H, Shahrokh Z, Schwall RH. Safety and antitumor activity of recombinant soluble Apo2 ligand. J Clin Invest 1999;104:155-62

Beg AA, Baltimore D. An essential role for $\mathrm{NF}-\mathrm{\kappa B}$ in preventing TNF- $\alpha$-induced cell death. Science 1996;274:782-84

Chaudhary PM, Eby M, Jasmin A, Bookwalter A, Murray J, Hood L. Death receptor 5, a new member of the TNFR family, DR4 induce FADD-dependent apoptosis and activate the NFKB pathway. Immunity 1997;7:821-30

Choi JH, Ahn KS, Kim J, Hong YS. Enhanced induction of Bax gene expression in $\mathrm{H} 460$ and $\mathrm{H} 1299$ cells with the combined treatment of cisplatin and adenovirus mediated wtp53 gene transfer. Exp Mol Med 2000;32:23-28

Degli-Esposti MA, Dougall WC, Smolak PJ, Waugh JY, Smith CA, Goodwin RG. The novel receptor TRAIL-R4 induces NF$\kappa \mathrm{B}$ and protects against TRAIL-mediated apoptosis, yet retains an incomplete death domain. Immunity 1997a;7:813-20

Degli-Esposti MA, Smolak PJ, Walczak H, Waugh J, Huang C $P$, DuBose RF, Goodwin RG, Smith CA. Cloning and characterization of TRAIL-R3, a novel member of the emerging TRAIL receptor family. J Exp Med 1997b; 186: 1165-70

Emery JG, McDonnell P, Burke MB, Deen KC, Lyn S, Silverman C, Dul E, Appelbaum ER, Eichman C, DiPrinzio R, Dodds RA, James IE, Rosenberg M, Lee JC, Young PR. Osteoprotegerin is a receptor for cytotoxic ligand TRAIL. J Biol Chem 1998;273:14363-67

Franco AV, Zhang X D, Van Berkel E, Sanders JE, Zhang $X$ Y, Thomas WD, Nguyen T, Hersey P. The role of NF-kappaB in TNF-related apoptosis-inducing ligand (TRAIL)-induced apoptosis of melanoma cells. J Immunol 2001;166:5337-45

Gerlier D, Thomasset N. Use of MTT colorimetric assay to measure cell activation. J Immunol Methods 1986;94:57-63

Gibson SB, Oyer R, Spalding AC, Anderson SM, Johnson G L. Increased expression of death receptor 4 and 5 synergizes the apoptosis response to combined treatment with etoposide and TRAIL. Mol Cell Biol 2000;20:205-12

Goke R, Goke A, Goke B, Chen Y. Regulation of TRAILinduced apoptosis by transcription factors. Cell Immunol 2000;201:77-82

Griffith TS, Chin WA, Jackson GC, Lynch DH, Kubin MZ. Intracellular regulation of TRAIL-induced apoptosis in human melanoma cells. J Immunol 1998;161:2833-40

Griffith TS, Lynch DH. TRAIL: a molecule with multiple receptors and control mechanisms. Curr Opin Immnuol 1998;10:559-63

Griffith TS, Ranch CT, Smolak PJ, Waugh JY, Boiani N, Lynch DH, Smith CA, Goodwin RG, Kubin MZ. Functional analysis of TRAIL receptors using monoclonal antibodies. J Immunol 1999a;162:2597-5

Griffith TS, Wiley SR, Kubin MZ, Sedger LM, Maliszewski C $\mathrm{R}$, Fanger NA. Monocyte-mediated tumoricidal activity via the tumor necrosis factor-related cytokine, TRAIL. J Exp Med 1999b;189:1343-53

Grotzer MA, Eggert A, Zuzak TJ, Janss AJ, Marwaha S, Wiewrodt BR, lkegaki N, Brodeur GM, Phillips PC. Resistance to TRAIL-induced apoptosis in primitive neuroectodermal brain tumor cells correlates with a loss of caspase-8 expression. Oncogene 2000;19: 4604-10

Gura T. How TRAIL kills cancer cells, but not normal cells. Science 1997;277:768

Jeremias I, Kupatt C, Baumann B, Herr I, Wirth T, Debatin K M. Inhibition of nuclear factor kappaB activation attenuates apoptosis resistance in lymphoid cell. Blood 1998;91:4624-31

Jia LQ, Osada M, Ishioka C, Gamo M, Ikawa S, Suzuki T, Shimodaira $\mathrm{H}$, Niitani $\mathrm{T}$, Kudo T, Akiyama M, Kimura $\mathrm{N}$, Matsuo M, Mizusawa H, Tanaka N, Koyama H, Namba M, Kanamaru R, Kuroki T. Screening the p53 status of human cell lines using a yeast functional assay. Mol Carcinogenesis 1997; 19:243-53

Jiang S, Song MJ, Shin EC, Lee MO, Kim SJ, Park JH. Apoptosis in human hepatoma cell lines by chemotherapeutic drugs via Fas-dependent and Fas-independent pathways. Hepatology 1999;29:101-10

Kang MS, Lee HJ, Lee JH, Ku JL, Lee KP, Kelley MJ, Won Y J, Kim ST, Park JG. Mutation of p53 gene in hepatocellular carcinoma cell lines with HBx DNA. Int J Cancer 1996;67: 898-902

Kayagaki N, Yamaguchi N, Nakayama M, Eto H, Okumura K, Yagita H. Type I interferons (IFNs) regulate tumor necrosis factor-related apoptosis-inducing ligand (TRAIL) expression on human T cells: a novel mechanism for the antitumor effects of type I IFNs. J Exp Med 1999;189:1451-60

Keane MM, Ettenberg SA, Nau MM, Russell EK, Lipkowitz S. 
Chemotherapy augments TRAIL-induced apoptosis in breast cell lines. Cancer Res 59:734-41

Kim K, Fisher MJ, Xu SQ, El-Deiry WS. Molecular determinants of response to TRAIL in killing of normal and cancer cells. Clin Cancer Res 2000;6:335-46

Kim KM, Lee K, Hong YS, Park HY. Fas-mediated apoptosis and expression of related genes in human malignant hematopoietic cells. Exp Mol Med 2000;32:246-54

Leverkus M, Neumann M, Mengling T, Rauch CT, Brocker E B, Krammer $\mathrm{PH}$, Walczak $\mathrm{H}$. Regulation of tumor necrosis factorrelated apoptosis-inducing ligand sensitivity in primary and transformed human keratinocytes. Cancer Res 2000;60: 553-59

Lin YZ, Yao SY, Veach RA, Torgerson TR, Hawiger J. Inhibition of nuclear translocation of transcription factor NFkappa B by a synthetic peptide containing a cell membranepermeable motif and nuclear localization sequence. J Biol Chem 1995;270:14255-58

Mongkolsapaya J, Cowper AE, Xu XN, Morris G, McMichael AJ, Bell JI, Screaton GR. Lymphocyte inhibitor of TRAIL (TNFrelated apoptosis-inducing ligand): a new receptor protecting lymphocytes from the death ligand TRAIL. J Immunol 1998;160:3-6

Mller $M$, Strand $S$, Hug $H$, Heinemann EM, Walter $H$, Hofmann WJ, Stremmel W, Krammer PH, Galle PR. Druginduced apoptosis in hepatoma cells is mediated by the CD95(APO-1/Fas) receptor/ligand system and involves activation of wild-type p53. J Clin Invest 1997;3:403-13

Nagane M, Pan G, Weddle JJ, Dixit VM, Cavenee WK, Huang $\mathrm{HJ}$. Increased death receptor 5 expression by chemotherapeutic agents in human gliomas causes synergistic cytotoxicity with tumor necrosis factor-related apoptosis-inducing ligand in vitro and in vivo. Cancer Res 2000;60:847-53

Oya M, Ohtsubo M, Takayanagi A, Tachibana M, Shimizu N, Murai M. Constitutive activation of nuclear factor-kappaB prevents TRAIL-induced apoptosis in renal cancer cells. Oncogene 2001;20:3888-96

Pan G, Ni J, Wei YF, Yu G, Gentz R, Dixit VM. An antagonist decoy receptor and a death domain-containing receptor for TRAIL. Science 1997a;277:815-18

Pan G, Ni J, Yu G, Wei YF, Dixit VM. TRUNDD, a new member of the TRAIL receptor family that antagonizes TRAIL signaling. FEBS Lett. 1998;424:41-45

Pan G, ORourke K, Chinnaiyan AM, Gentz R, Ebner R, Ni J, Dixit V. The receptor for the cytotoxic ligand TRAIL. Science 1997b;276:111-13

Park JG, Lee JH, Kang MS, Park KJ, Jeon YM, Lee HJ, Kwon HS, Park HS, Yeo KS, Lee KU, Kim ST, Chung JK, Hwang Y J, Lee HS, Kim CY, Lee YI, Chen TR, Hay RJ, Song SY, Kim WH, Kim CW, Kim Yl. Characterization of cell lines established from human hepatocellular carcinoma. Int $\mathrm{J}$ Cancer 1995;62:276-282

Pitti RM, Marsters SA, Ruppert S, Donahue CJ, Moore A, Ashkenazi A. Induction of apoptosis by Apo-2 ligand, a new member of the tumor necrosis factor cytokine family. J Biol Chem 1996;271:12687-90
Schneider P, Thome M, Burns K, Bodmer JL, Hofmann K, Kataoka T, Holler N, Tschopp J. TRAIL receptors 1 (DR4) and 2 (DR5) signal FADD-dependent apoptosis and activate NFKB. Immunity 1997;7:831-36

Screaton GR, Mongkolsapaya J, Xu XN, Cowper AE, McMichael AJ, Bell Jl. TRICK2, a new alternatively spliced receptor that transduces the cytotoxic signal from TRAIL. Curr Biol 1997;7: 693-96

Sells MA, Chen ML, Acs G. Production of hepatitis B virus particles in Hep G2 cells transfected with cloned hepatitis $B$ virus DNA. Proc Natl Acad Sci USA 1987;84:1005-08

Sheridan JP, Marsters SA, Pitti RM, Gurney A, Skubatch M, Baldwin D, Ramakrishnan L, Gray CL, Baker K, Wood WI, Goddard AD, Godowski P, Ashkenazi A. Control of TRAILinduced apoptosis by a family of signaling and decoy receptors. Science 1997;277:818-21

Shin EC, Shin JS, Park JH, Kim JJ, Kim H, Kim SJ. Expression of Fas-related genes in human hepatocellular carcinomas. Cancer Lett 1998;134:155-62

Takeda K, Hayakawa Y, Smyth MJ., Kayagaki N, Yamaguchi N, Kakuta S, Iwakura Y, Yagita H, Okumura K. Involvement of tumor necrosis factor-related apoptosis-inducing ligand in surveillance of tumor metastasis by liver natural killer cells. Nat Med 2001;7:94-100

Thomas WD, Hersey P.TNF-related apoptosis-inducing ligand (TRAIL) induces apoptosis in Fas ligand-resistant melanoma cells and mediated CD4 T cell killing of target cells. $\mathrm{J}$ Immunol 1998;161:2195-200

Van Antwerp DJ, Martin SJ, Kafri T, Green DR, Verma IM. Suppression of TNF- $\alpha$-induced apoptosis by NF- $\kappa B$. Science 1996;274:787-89

Walczak H, Degli-Esposti MA, Johnson RS, Smolak PJ, Waugh JY, Boiani N, Timour MS. TRAIL-R2: a novel apoptosismediating receptor for TRAIL. EMBO J 1997;16: 5386-97

Walczak H, Miller RE, Ariail K, Gliniak B, Griffith TS, Kubin M, Chin W, Jones J, Woodward A, Le T, Smith C, Smolak P, Goodwin RG, Rauch CT, Schuh JC, Lynch DH. Tumoricidal activity of tumor necrosis factor-related apoptosis-inducing ligand in vivo. Nat Med 1999;5:157-63

Wang CY, Mayo MW, Baldwin AS. TNF- $\alpha$ and cancer therapy-

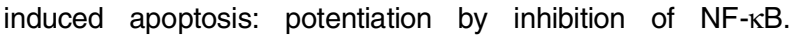
Science 1996;274:784-87

Wiley SR, Schooley K, Smolak PJ, Din WS, Huang CP, Nicholl JK, Sutherland GR, Smith TD, Raunch C, Smith CA, Goodwin RG. Identification and characterization of a new member of the TNF family that induces apoptosis. Immunity 1995;3:673-82

Wu SG, Burns TF, McDonald ER, Jiang W, Meng R, Krantz I D, Kao G, Gan D D, Zhou JY, Muschel R, Hamilton SR, Spinner NB, Markowitz S, Wu G, El-Deiry WS. Killer/DR5 is a DNA damaga-inducible p53-regulated death receptor gene. Nat Genetics 1997;17:141-43

Yamanaka T, Shiraki K, Sugimoto K, Ito T, Fujikawa K, Ito M, Takase K, Moriyama M, Nakano T, Suzuki A. Chemotherapeutic agents augment TRAlL-induced apoptosis in human hepatocellular carcinoma cell lines. Hepatology 2000;32:482-90 